\title{
Virtual Realities: How Remote Dwelling Populations Become More Remote Over Time despite Technological Improvements
}

\section{Dean Carson $^{1, *}$ and Jen Cleary ${ }^{2}$}

1 School for Social and Policy Research, Charles Darwin University, Darwin, Northern Territory, 0909, Australia

2 Centre for Rural Health and Community Development, University of South Australia, 111 Nicolson Avenue, Whyalla Norrie, South Australia, 5608, Australia; E-Mail: jen.cleary@unisa.edu.au

* Author to whom correspondence should be addressed; E-Mail: dean.carson@cdu.edu.au; Tel.: +61-447-085-520.

Received: 8 April 2010; in revised form: 27 April 2010 / Accepted: 3 May 2010 /

Published: 10 May 2010

\begin{abstract}
For those who have access to them, technologies of various sorts play a key role in maintaining connections between small and geographically dispersed settlements and to the wider World. For technologies to work in remote areas, there must be a framework of adaptability which ensures that users can adapt their practices to suit the new technology, technologies can be customised for local conditions, and an institutional infrastructure (including a regulatory environment) allows these adaptations to occur. In recent times, remote Australia's "power to persuade" government to consider its needs when designing regulatory environments has diminished as a result of the changing nature of remote economies. This paper uses two case examples - that of air transport technology and that of communications technology-to demonstrate how a poor regulatory environment in effect increases the isolation of remote settlements. In the case of air transport, over regulation has made the cost of adoption and access too high for many remote dwellers. In the case of communications technology, de-regulation has made it difficult for remote dwellers to demand equity of access to infrastructure. We conclude by suggesting that regulatory systems need to be more aware of the unique conditions facing remote populations. Research into the persistently low rates of technology adoption in remote areas needs to be more cognizant of the regulatory adaptability aspect.
\end{abstract}


Keywords: technology adoption; regulatory system; remote Australia; air transport regulation; communications technology

\section{Introduction}

The sustainability of human populations in remote areas, particularly of developed nations, is dependent on how well they adapt to the problems of sparsity [1]. The problems of sparsity are essentially problems maintaining connections among small and geographically dispersed settlements and between these settlements and larger centres elsewhere. Connections are essential for the exchange of goods and services and the maintenance of social networks, but are inherently fragile because of long distances, economies of scale, and harsh environments. Technologies of various sorts play a critical role in managing sparsity [2]. For technologies to "work" in remote areas, there must be a framework of adaptability which includes users who can adapt their practices to suit the new technology, technologies which can be customised for local conditions, and an institutional infrastructure (including a regulatory environment) which allows adaptation [3].

There has been much less written about how the adaptability of the regulatory environment affects connections in remote Australia than about the issues of user adaptability [4,5] and technical adaptability [6,7]. This paper examines the changing regulatory environment around two technologies that have played a critical role in connecting remote Australia - air transport and personal telecommunications. We postulate what changes in the regulatory environment have meant for remote dwellers seeking to maintain connections. We argue that a better understanding of the adaptability of the regulatory environment is needed when trying to understand the continuing poor rates of technology adoption that have been observed in remote areas here and around the World [8].

The paper first describes a general framework for technology adoption, presenting the argument that adoption is often an outcome of successful adaptation to local conditions: by the user of their own practices; of the technology itself; and of the regulatory environment. We then examine how the changing economic role of remote Australia might influence the capacity of users there to influence the regulatory environment [9]. We present two case studies of technology development and its adoption in remote Australia, with a focus on the regulatory aspects of the development. The case studies draw material from policy documents and reviews and commentaries relating to those documents. Their aim is to identify the importance of regulatory environments rather than to quantify impacts of regulatory change on remote dwellers. We conclude with a discussion of what the experiences in these two cases might mean for the adoption of current and future technologies irrespective of the adaptability of users and technologies themselves.

\section{A General Framework for Technology Adoption in Remote Australia}

A number of general approaches have been suggested to enhance the sustainability of human settlements in remote areas. The "frontier" approach has been to encourage population growth through migration [10], although this has proven difficult to achieve as in-migrating populations tend to 
congregate in a few larger centres, leaving a pattern of very small, very isolated settlements (sparsity) elsewhere [1]. A contrasting approach has been to force the closure of settlements deemed particularly unsustainable, as occurred in Newfoundland in Canada in the 1960s [11]. Communities targeted for closure have proven surprisingly resistant, often due to the cultural ties of Indigenous people [12]. Weeden [13] proposed a splitting of populations, with Indigenous people left to continue traditional living practices (presumably sustainable ones), and non-Indigenous people acting as temporary residents to work within the new economies (often centred on resource extraction) of remote areas. Indeed, the proportion of temporary populations (fly-in/ fly-out workers, seasonal workers and visitors) in many remote areas appears to have increased over the past several decades [14]. This transition (particularly in the labour force structure) has been facilitated by improvements in transport and communications technology [15]. Technology change has not only improved the ease of access and egress to/from remote settlements, but has enabled people to remain in contact with one another-whether it be worker with manager [16], spouse with spouse [17], or consumer with supplier [18]. Improving technology is lauded as a pathway to improved socio-economic status [19], improved health service delivery [20], and improved delivery of government services [21] among other things.

While the literature is generally very positive about the benefits of improved transport and communications technologies for people who live and/or work in remote areas, there are also concerns raised about the capacity of remote dwellers to exploit technology to their benefit. Weymouth and colleagues [16], for example, noted that technologies which enabled better long distance management of nursing professionals also served to emphasise the physical difference between practitioner and manager because they reduced the perceived need for face to face visits. Burke and colleagues [17] noted that men and women had different attitudes to the way in which information and communication technology (ICT) assisted the maintenance of long distance relationships. Cunningham and colleagues [18] pointed out that ICT and improved transport infrastructure offered opportunities to remote Aboriginal businesses only if they could be adapted to local conditions such as irregular access and seasonal variations in usage patterns. Cleary and colleagues [22] emphasised this point, noting that ICT and transport systems are usually designed and managed by urban based participants in the supply chain, who are consequently well positioned to use them to exploit remote businesses.

The literature cited here summarises the three foundational attributes of a general technology adoption model [3]. Successful technology adoption requires certain skills and attributes of the user (the user must be willing to adapt to the new technology), the technology itself (it must be adaptable to the local circumstances of the user), and the implementation environment. The implementation environment includes how well the technology is publicised and promoted in the media and the support provided for adoption by education, funding and regulatory systems $[23,24]$. The last of these is particularly important, as the implementation of any new technology requires the resolution of conflict between competing local "adaptations" (or the approval of multiple adaptations).

The government role in technology adoption is supposed to be one of promoting technology use, providing the underlying infrastructure, investing in the necessary education and training, and occasionally providing direct funding and tax incentives for adoption, as well as regulating the operation of manufacturers, suppliers and users [25]. In the western democratic system, government intervention in such processes is to ensure some level of equity (spatial and demographic) of access to 
new technologies [26]. Governments therefore regulate to permit commercialisation of a technology, to promote its adoption, and to ensure equity of access. However, governments like those in Australia need to balance the desire for equity with the "free market" economic approach which is supposed to let the market decide what technologies are viable in what locations for what users [27]. Government, it is believed, should only step in when there is demonstrated failure by the market to efficiently allocate resources.

Recognising that it is not always easy to demonstrate market failure (or identify its causes and appropriate responses), Stenzel and Frenzel [28] emphasised the role of "corporate political activity" in the development of regulations around technological change. They described the conflicting interests of new and established energy companies in regard to renewable energy policy in various European nations. They showed how some established companies, because of their strong links to the regulatory system, were able to adapt subsidy schemes to suit their local conditions at the expense of other stakeholders in the system. Gottweis [29] notes that it is practically impossible to identify and integrate the views of all people in the policy making process, and so governments are forced to make decisions about from whom they hear (and then how they respond). Brett [9] claims that these decisions are influenced by various stakeholders" "power to persuade".

Studies of the rural-urban digital divide in Australia have started to suggest that the domination of urban stakeholders in the design and regulation of new technologies have disadvantaged rural dwellers [19]. Rural and remote dwellers are generally seen as highly adaptable people who are willing to adopt new technologies they see as beneficial [4]. The popular image of "the bush" in Australia includes the notion of "bush ingenuity" which is specifically about using locally available material to customise technology [30]. This notion has been persistent and rarely challenged, despite the observed slower rates of adoption of many technologies by Australia's rural dwellers compared to their urban counterparts [31]. It may be, then, that a diminishing "power to persuade" is a greater issue with regard to low levels of adoption than are user or technological factors (although the three are clearly related).

\section{Remote Australia's Power to Persuade}

Brett [9] argued that "changes in Australia's economy, demography, and political culture" have fundamentally changed the political relationship between urban and rural dwellers. In the past, rural economic power and the value of rural origin goods (food, minerals etc.) meant that extra costs of managing rural populations (particularly through provision of transport, communication and governance infrastructure) were an accepted part of national policy. As economic power diminished, so did justification for "special deals" for rural dwellers. In essence, those who were remote from centres of political power became more remote as their economic leverage weakened. Brett's argument holds up well when applied to the transition Australia's economy made from "riding the sheep's back" [32] to more urban based economies in the 1970s and 1980s.

While there has been a recent resurgence of Australia's (primarily remote based) mining industry, the resultant political power [33] has not accrued to remote dwelling people as one might expect. This is because of fundamental changes in the relationship between mining (and pastoralism) sectors and settlement patterns. Up until as recently as the 1970s and 1980s, the Australian frontier myth was largely driven by a perception of the necessity of human settlement in rural and remote areas to 
provide labour and support for the critical primary industries [34]. The popular perception of remote settlements was then of small but important centres occupied by pastoral and mining families and the people who served them. Frontier expansion was accompanied by repatriation and removal of Aboriginal people, making it clear that the valued populations were the new settlers [35]. Remote settlements were also valued because of the role they played in hosting defence personnel and because they serviced essential transport and communications infrastructure [36].

In more recent times, both pastoralism and mining have become far more labour efficient in the locations of extraction, transport and communications infrastructure have become more and more centred in large urban settlements, and the residual remote area workforce has been more populated by temporary, fly-in/ fly-out and seasonal labour [14]. The work that these people do is still important, but their concerns are for access to land for extractive industries, not for sustaining social structures in remote settlements. The pattern of settlement has changed from numerous small but well serviced, economically active centres to less numerous, less well serviced, and often economically stagnant outposts. Within this general pattern are four types of human settlement:

1. Isolated Indigenous communities, usually artificially created during the period of removal and repatriation, often located intentionally distant from sites of (settlers') economic activity and so continually struggling to establish an economic justification for existence [35];

2. Service towns that have seen services decline, have lost population, and are now largely viewed as service centres for disadvantaged populations [37,38] rather than as locations of hope and opportunity [39]. Even the few larger towns (Alice Springs, Broken Hill, Mt Isa, Kalgoorlie) have become problematised as they struggle to manage the split between wealthy and often temporary mining (and government services) labour and disadvantaged Indigenous populations who congregate there to access services [40];

3. Mining and other special purpose towns (tourism, defence) which are designed to be temporary (or exclusive) and as such are largely divorced from the sustainability challenges that surround them [41,42];

4. Isolated farm/ pastoral settlements with very small populations based on family or company ties and experiencing population fluctuations around seasonal work [43]. These settlements were once inimically tied to political power through Australia's very localised version of local government. Local government reform in the last twenty or thirty years, however, has removed the local power base [44].

The outcome, then, has been that the economic power held by remote based industries has largely shifted to urban dwellers (who work from a distance or temporarily fly-in/fly-out to remote locations), the settler populations remaining in remote areas have become more distant from the seats of political power (even at local government level) and the increasing prominence of Indigenous populations has not been accompanied by a new economic power base. In fact, the power bases for Indigenous politics have largely (and logically) been in the major (southern) urban centres where there is more immediate access to education, lobbying partners and politicians [34].

The change in settlement patterns has led to a change in (particularly national) government policy towards remote areas. The search for economic justification for population growth continues (see, for 
example, the activities of the Northern Australia Land and Water Taskforce [45] and the continuing push for defence-force growth [46]). Beyond these economic initiatives, however, is a policy of remediation - a search for strategies to address (primarily Indigenous) disadvantage. The wealth generated by these measures tends to flow to urban based bureaucrats, lobbyists and consultants. The policy approach is one of imposing solutions as witnessed dramatically in the forced occupation of Northern Territory remote Indigenous communities by the Australian Defence Forces in 2007 [40]. The potential for new economies (and then perhaps, new models of remote Indigenous power broking) arising out of remote Indigenous culture and environmental knowledge [47,48] has been mooted, but as yet there has been little evidence that neo-liberal economic approaches sit well with culturgenic [49] imperatives.

Remote Australia (at least from a human geography perspective) has become a problem for the regulatory system (which is based outside). Improved transport and communications technologies have made it easier for externally based people to exploit and police remote areas. The development of these technologies has, in fact, been focused on that process [50]. Even new industries like tourism, promoted as providing great opportunity for local development, have adopted the external focus that applies to mining, pastoralism and service provision [51]. Two case studies of technology change highlight how remote Australia has become more distant from the regulatory system, and how this has affected remote dwellers' capacity to benefit from technological change. In the case of air transport, intensive regulation has made it increasingly difficult to make local adaptations. In the case of telecommunications, de-regulation has had a similar effect.

\section{The Increasing Regulation of Air Transport}

Civil aviation regulation in Australia has its roots in the 1920s, when the Australian Government passed the Air Navigation Act of 1920 and initiated a tender process to establish aerial mail services over particular routes. The first of these routes included Sydney-Brisbane, but significantly, the remainder were between remote locations such as the farming communities of Charleville-Cloncurry in Queensland and the mining communities of Geraldton-Derby in Western Australia. The imperative was to provide a means of communication between economically important, but isolated settlements, and air transport was seen as the facilitating technology [65]. Promotional material of the time heralded a "new era" of accessibility both to, but importantly, between remote locations. Indeed, Qantas [53], currently Australia's largest international passenger airline, was financed by a pastoralist and first headquartered in Cloncurry, in Queensland's remote north west. Aviation technology was initially readily adopted in remote settlements and adapted to local conditions. Aircraft which could use short, unsealed airstrips (which were expensive to build and maintain) were used, and Qantas' early routes included passenger services between at least 8 remote settlements.

At around the same time as the airmail and passenger services were developing, the Australian Inland Mission Aerial Medical Service (later renamed the Royal Flying Doctor Service) was founded in Cloncurry, Queensland by the Reverend John Flynn. Its primary purpose was to provide an emergency aerial medical service to those in remote locations. By the mid-1930s, RFDS operations covered most of remote Australia and in 1950, then Prime Minister Sir Robert Menzies acknowledged 
the RFDS as "...perhaps the single greatest contribution to the effective settlement of the far distant country that we have witnessed in our time" [54].

Remote and regional settlements continue to depend on air services for economic, social and medical access. Traffic is two-way, i.e., regional and remote populations accessing larger service centres and service providers accessing regional and remote centres. Regular passenger transport (RPT) routes both competitive (open market access) and exclusive (restricted or no competition and/or subsidized by governments) [55] are operated by commercial airlines. Charter operators provide services for specific purposes in some remote regions, e.g., firefighting; mail services; aerial photography; pasture mapping; and livestock mustering. Not for profit services such as the RFDS and "Angel Flight" provide routine and emergency aero-medical services to remote settlements. Privately owned and operated aircraft also operate in remote settlements.

Civil aviation in Australia is regulated by the Civil Aviation Safety Authority (CASA), an Australian Government agency which regulates both commercial aviation (CA) and general aviation (GA) under the federal Civil Aviation Act (1988) through Civil Aviation Regulations [56]. These are gradually being replaced by Civil Aviation Safety Regulations [57]. These regulations have had an increasingly significant negative impact for those seeking to exploit aviation technology in remote settlements. Issues relate to licensing, flying operations, aircraft maintenance, airspace controls, airport security, and even airfield design. Over time, critical components of the regulatory system have come to be restricted in location to the larger urban centres. For example, pilots in Australia are required to undergo medical checks by CASA-endorsed doctors at regular intervals. Accredited doctors tend not to be found practising in regional or remote locations, because the sheer lack of volume does not defray the cost of maintaining CASA accreditation. Similarly, even the most minor maintenance to an aircraft e.g., changing a tyre; fitting a new bearing; changing seat belt fittings; replacing a windscreen or minor servicing must be undertaken by a Licensed Aircraft Mechanical Engineer (LAME). Again, there are few of these located outside of the major urban centres.

Increasing (regulated) specialisation has also made it more difficult to effectively exploit air transport technologies in remote Australia. Air Operators Certificates (AOC) specify the activities that can be undertaken by specific aircraft/operators. This specificity has impacted significantly on remote communities as economies of scope are not possible. For example, in the 1980s and into the 1990s, the RFDS would routinely carry non-health professionals on flights into remote communities. These professionals provided much needed services and included vets, IT professionals, health administrative staff, and financial services professionals. The strict AOC conditions mean that these non-health professionals can no longer be carried on the regular, routine, non-emergency health flights to remote communities where RPT services do not operate. This is despite the fact that seats are usually available and the non-health professionals and their organisations would willingly pay to access the service.

Increasingly, then, aerial services become restricted to the small number of RPT airports in remote Australia. These airports are owned and managed primarily by local government authorities or private interests. Those which were previously federally owned were handed over to local government control in the 1980s [58]. RPT airports tend to maintain fuel supplies and provide (limited) access to LAMEs. However, operating to and from RPT airports brings remote flyers into contact with Australia's "one size fits all" airport security regulations. Any airport with RPT status regardless of location, requires a higher level of security than non-RPT airports. Security clearance is mandatory for airside access at 
RPT airports, regardless of their size or the volume of traffic they handle. Obtaining a security clearance requires extensive background checking and high annual fees. Maintaining higher security levels requires expensive infrastructure like security fencing; coded and sometimes alarmed gates. Additional security measures may include baggage and people screening. The technology itself is not only costly to install and maintain, the cost of staff to operate it is also high.

The costs of securing regional RPT airports have also influenced accessibility in terms of airfield design. Light aircraft of the type most often used in remote settlements are more likely to require a cross-strip to support safe landings that can be undertaken irrespective of wind direction. Fencing such a runway with approved security fencing is expensive, and the costs of both maintaining the cross-strip and fencing the greater area are sometimes prohibitive. The alternative is to cease maintenance of the cross-strip, and accommodate the (usually larger) RPT aircraft only. This also means that the non-required land can then be sold off and/or used for non-aviation, commercial purpose, increasing the short term gain for the airport operators [58]. The flow on effects are manifold - the immediate impact is that the airport can only be used by some aircraft some of the time, thus limiting access to fuel and other services. Aeroclubs and flight schools have suffered from this lack of access [59], and as they shut down, they take with them LAMEs and maintenance facilities, access to out of hours refuelling services, and pilot training services.

\section{The De-regulation of Communications Technology}

Alongside the development of Qantas, the Reverend John Flynn established the Royal Flying Doctor Service (RFDS). The RFDS required the maintenance of communication services across the vast inland area that it serviced. Alfred Traeger developed a pedal radio (modified from those used in the trenches of WW1) in 1927 and worked with Flynn to establish it as a viable means of distance communication. The user was able to generate power to operate the unit via the pedals, thus leaving the hands free to operate the radio. The units transmitted Morse code via a keyboard, with the correct Morse signal being sent when the corresponding key was struck - meaning that a knowledge of Morse code was not necessary. The pedal radio enabled the development of an increasingly larger virtual local network in remote Australia. There was little regulation at this time, the only requirements being an identifying callsign and a strong pair of legs to generate the energy to power the radio.

As the service improved and was refined, voice communication was enabled via single side band (SSB) transceivers. The transmission of telegrams and later radio to telephone services were undertaken by the RFDS Base operators, in addition to the medical services the RFDS provided. Radio users were able to be "patched" through to the national telephone network to conduct conversations. These were able to be heard by anyone listening on the appropriate frequency and had the effect of ensuring that those within the network were privy to the everyday happenings of their peers-their health issues, family and business matters. The RFDS operated its telecommunication functions under licence to the Australian Government through the Post Master General (PMG), and later Telecom Australia and then Telstra. Billing for telephone calls was administered by the RFDS. Calls were limited to six minutes and charged in three minute increments. By the technological standards of today, the service was crude, but effectively adapted for local conditions. People were connected, and those in one's "local" network could include people vastly separated by distance. Additional radio 
frequencies were available on RFDS transceivers for everyday use between radio users and were known as "chatter channels".

RFDS transceivers were also used to conduct "School of the Air" lessons for remote and isolated primary school children for many years. The service was introduced by Miss Adelaide Miethke in 1946 (who was vice president of the RFDS SA Branch at the time). She noticed that children in remote locations were taught to use the RFDS transceivers, and could see the potential for these to be adapted to delivering lessons. The School of the Air (SotA) was established in other states during the 1950s. Up until that time, remote and isolated children either had to attend boarding schools or receive their lessons by mail. These links between telecommunications services and government priority activities (health and education) meant that the Commonwealth Government in particular was active in ensuring technology availability and adaptability. By the 1980s, this meant increasing provision of telephone services in remote areas by the government telecommunications business (Telecom) under government direction.

Until 1988, the provision of telecommunications in Australia was the responsibility of the Australian Government. This came about largely as the result of the requirement to coordinate international telecommunications across the colonies, and, almost by default, domestic service provision was included. There was considerable discussion leading up to federation, that federal power over postal and telecommunications services should in fact be limited to the international context. However, as history shows, this didn't happen (but does go some way to explaining why telecommunications became the province of the Federal Power and railways, for example, did not).

In 1959, a major change occurred, when the Post Office was required to become self funding. The end of Australian Government involvement as a service provider of telecommunications in Australia occurred in 1988. The "Evans Statement" (as it became known) outlined a new framework for telecommunication services, which removed restrictions on the ability of service providers to enter the Australian Telecommunications market. The principal policy objective was stated as being the provision of telephone services throughout Australia on a non-discriminatory, uniform basis at affordable prices.

Recognising that remote areas were unlikely to be priority business for private telecommunications companies, the Australian Government introduced service obligations and regulated these through licensing arrangements. The Evan's Statement declared that "the needs of rural Australia have been given special status in this context..." [60]. Service obligation guarantees were intended to mitigate the effect of geography and sparsity for populations who would otherwise be marginalised by market forces. Service obligation guarantees, however, have become increasingly difficult to enforce (because of the complexity of the technologies and corporate structures), and increasingly limited to technologies that are rapidly becoming outdated (fixed line telephone services, for example).

The Internet has become a standard communication mechanism across personal and business communications; mobile telephony has increased in Australia from 3.2 million mobile services in 1996 to over 20 million in 2008; and public broadcasting across AM, FM and digital networks has increased. A recent Review of Regional Telecommunications in Australia [60] notes that the regulatory framework (and particular service obligations) has struggled to keep pace with these technological changes. The consistent outcome has instead been a failure to deliver many of these technologies (or substantially delayed delivery) to remote areas. Current examples include limited coverage of mobile 
phone services and digital radio services beyond any but the larger towns in remote Australia. The impacts on development of small business in remote Australia have been noted [22] with a review of the bush foods industry [61] for example demonstrating how that market remains largely unexploited by local Aboriginal people with poor access to communications technology. Instead, information and resource flows are controlled by a small number of individuals and businesses (usually located outside the region) who are "connected".

The Australian Government has proven loathe to be seen to be imposing further regulation on a de-regulated industry, and so, while rural and remote dwellers have enthusiastically embraced the potential for new technologies to improve their quality of life (replacing RFDS "chatter channels" with online social networking applications, for example), their capacity to access the technology has remained limited.

\section{Conclusions}

The two cases presented here provide some evidence of how remote locations may become more remote over time as their power to persuade decreases and the gap between the technologies available in urban and remote areas increases. Our focus here has been on the adaptability of the regulatory environment. That environment is poorly adaptive and, importantly, without the power to persuade, remote populations struggle to even raise this as an issue with policy-makers. Over regulation tends to demand resources to facilitate uptake that are simply not available (or very difficult to get) in remote areas. It also means that where efficient economies of scope might be developed and maintained (health service and business travel sharing air transport infrastructure, for example), they become unachievable. De-regulation exacerbates the already disadvantaged economic position of remote areas - their inability to generate economies of scale (by providing sufficient customers to attract a telecommunications provider, for example). Governments continue to tout the value of new technologies for remote dwellers, without, we posit, an understanding that government intervention (or lack of intervention) may be depriving those dwellers of the chance to realise that value. What is required is that remote communities be re-engaged in corporate political activity-not as problematised populations who demand remedial services, but as resourceful and innovative populations who have demonstrated in the past a capacity to lead Australia's technological progress. This may be particularly important in relations between government and Indigenous populations who have failed to thrive despite (and perhaps because of) their position at the centre of government thinking about remote Australia.

The major contribution of this paper has been to focus attention on the regulatory adaptability component of the general model for technology adoption. The other components (user adaptability and technology adaptability) remain critical, and we are not attempting to argue that poor regulatory adaptability is the only, or even the major explanation for the persistence of the rural-urban technology divide. We have presented here just two examples of the impact of poorly adapted regulatory frameworks on remote settlements. Further research, based on more extensive and systemic examination of technology adoption in remote settlements is required. Such investigation that further explores our claims that poorly adapted regulatory systems essentially increase the isolation of remote areas over time, will provide the evidence base that will be required to effect change. There are rich 
data available in the Australian context via submissions from remote dwellers to innumerable public policy reviews, for example. An examination of these, together with a systemic review of processes which are used to engage remote dwellers in policy development and review will achieve two key outcomes:

- Provide new ways of thinking about how policy is conceived and its regulatory frameworks are constructed and enacted that take account of different contexts in which this needs to occur, thus addressing the diversity issue.

- Determine the most effective ways of ensuring that remote voices are properly heard, thus reinstating their "power to persuade".

\section{References and Notes}

1. Gloersen, E.; Dubios, A.; Roto, J.; Rasmussen, R.; Sterling, J. Development Perspectives for the NSPA: Opportunities and Challenges; NORDREGIO: Stockholm, Sweden, 2009; Avaliable online: http://www.nordregio.se. Accessed 15 September, 2009 (accessed on 24 February 2010).

2. Stafford Smith, M. The desert syndrome'-causally-linked factors that characterize outback Australia. Rangeland J. 2008, 30, 3-14.

3. Straub, E. Understanding technology adoption: Theory and future directions for informal learning. Rev. Educ. Res. 2009, 79, 625-649.

4. Rola-Rubzen, M.F.; McGregor, M. Impact of the Desert Economy. In Proceedings of the Desert Knowledge Symposium 2008, Desert Knowledge CRC, Alice Springs, Australia, 3-7 November 2008; Available online: http://www.desertknowledgecrc.com.au/publications/downloads/ DKCRC_Impact-of-the-Desert-Economy.pdf (accessed on 3 March 2010).

5. Kartiwi, M.; MacGregor, R.C. Electronic commerce adoption barriers in small to medium-sized enterprises (SMEs) in developed and developing countries: A cross-country comparison. J. Electron. Comm. Organ. 2007, 5, 35-51.

6. O’Neil, D. Assessing community informatics: A review of methodological approaches for evaluating community networks and Community Technology Centres. Internet Res. Electron. Netw. Appl. Policy 2002, 12, 76-102.

7. Dyson, L.E.; Hendriks, M.A.N.; Grant, S. Information Technology and Indigenous People; Information Science Publishing: Hershey, PA, USA, 2007.

8. Chinn, M.D.; Fairlie, R.W. The determinants of the global digital divide: A cross-country analysis of computer and internet penetration. Oxford Econ. Pap. 2007, 59, 16-44.

9. Brett, J. The country, the city and the state in the Australian settlement. Aust. J. Polit. Sci. 2007, $42,1-17$.

10. Gylfason, T. Natural resources education and economic development. Eur. Econ. Rev. 2001, 45, 847-859.

11. Kennedy, J.C. At the crossroads: Newfoundland and Labrador communities in a changing international context. Can. Rev. Sociol. Anthropo.l 1997, 34, 297-317.

12. Farish, M.; Lackenbauer, P.W. High modernism in the Arctic: Planning Frobisher Bay and Inuvik. J. Hist. Geogr.2009, 35, 517-544. 
13. Weeden, R.B. Northern people, northern resources, and the dynamics of carrying capacity. Arctic 1985, 38, 116-120.

14. Storey, K. Commute Work, Regional Development and Settlement Strategies. In Proceedings of the Conference on The Role of the State in Population Movements: The Circumpolar North and Other Periphery Regions, Arctic Centre, Rovaniemi, Finland, 26-28 October 2009.

15. Carter, T.; Kaczmarek, E. An exploration of Generation Y's experiences of off-shore fly-in/fly-out employment. Aust. Community Psychol. 2009, 21, 52-66.

16. Weymouth, S.; Davey, C.; Wright, J.I.; Nieuwoldt, L.; Barclay, L.; Belton, S.; Svenson, S.; Bowell, L. What are the effects of distance management on the retention of remote area nurses in Australia? Rural Remote Health 2007, 7, No. 652; Available online: http://www.rrh.org.au (accessed on 10 March 2010).

17. Burke, R.J.; Matthieson, S.B.; Einarsen, S.; Fiskenbaum, L.; Soiland, V. Gender differences in work experiences and satisfactions of Norwegian oil rig workers. Gend. Manag. Int. J. 2008, 23, 137-147.

18. Cunningham, A.B.; Garnett, S.T.; Gorman, J. Policy lessons from practice: Australian bush products for commercial markets. Geo J. 2009, 74, 429-440.

19. Willis, S.; Tranter, B. Beyond the "digital divide": Internet diffusion and inequality in Australia. J. Sociol. 2006, 42, 43-59.

20. Parkinson, C.; Hudson, L.; Hornsby, D.; Madl, R.; Collins, N. Telehealth: A national, sustainable approach. In Proceedings of the 7th National Rural Health Conference, Hobart, Austalia, 1-4 March 2003; Available online: http://nrha.ruralhealth.org.au/conferences/docs/7thNRHC/ Papers.htm (accessed on 10 March 2010).

21. Gauld, R.; Goldfinch, S.; Horsburgh, S. Do they want it? Do they use it? The "demand-side" of e-government in Australia and New Zealand. Govt. Inform. Quart. 2010, 27, 177-186.

22. Cleary, J.; McGregor, M. J.; Bryceson, K.; James, C. In Proceedings of the Australian Rangelands Conference: Development of a Value-Driven Bush Foods Industry Chain that Rewards Aboriginal People, Charters Towers, Austalia, 28 September-2 October 2008; Available online: http://desertknowledgecrc.com.au/publications/downloads/DKCRC_Development-of-aValue-Driven-bush-foods-industry-chain-that-rewards-Aboriginal-people.pdf (accessed on 23 April 2010).

23. Majchrzak, A.; Rice, R.E.; Malhorta, A.; King, N.; Ba, S. Technology adaptation: The case of a computer-supported inter-organizational virtual team. MIS Quart. 2000, 24, 569-600.

24. Antonelli, C. Diffusion as a process of creative adoption. J. Technol. Transfer 2006, 31, 211-226.

25. Seeman, E.D.; O'Hara, M.T.; Holloway, J.; Forst, A. The impact of government intervention on technology adoption and diffusion: The example of wireless location technology. Electron. Govert 2007, 4, 1-19.

26. Huffman, L.S. Comparative review of foreign direct investment policies for telecom services in the United States, India and Australia: Why back to the multilateral future is the best choice for states, consumers, and suppliers. Emory Int. Law Rev. 2008, 22, 283-316; Available online: http://www.law.emory.edu/fileadmin/journals/eilr/22/22.1/Huffman.pdf (accessed on 13 March 2010).

27. Feil, M. The Failure of Free Market Economics; Scribe Publications: Carlton, Australia, 2010. 
28. Stenzel, T.; Frenzel, A. Regulating technological change-the strategic reactions of utility companies towards subsidy policies in the German, Spanish and UK electricity markets. Energ. Policy 2008, 36, 2645-2657.

29. Gottweis, H. Participation and the new governance of life. Biosocieties 2008, 3, 265-285.

30. Wildman, P. How futuring bush mechanics seek to transform the World. Futures 2007, 39, 569-582.

31. Atkinson, J.; Black, R.; Curtis, A. Exploring the digital divide in an Australian regional city: A case study of Albury. Aust. Geogr. 2008, 39, 479-493.

32. Cashin, P.; Mcdermott, C.J. 'Riding on the sheep's back': Examining Australia's dependence on wool exports. Ec. Rec. 2002, 78, 249-263.

33. Hay, J.L. Challenges to liberalism: The case of Australian energy policy. Resour. Policy 2009, 34, 142-149.

34. Instone, L. Northern belongings: Frontiers, fences, and identities in Australia's urban north. Environ. Plan. A 2009, 41, 827-841.

35. Prout, S.; Howitt, R. Frontier imaginings and subversive Indigenous spatialities. J. Rural Stud. 2009, 25, 396-403.

36. Carson, D. Population policies at the edge: The demographic ambitions of frontiers. In Demography at the Edge: Remote Human Populations in Developed Nations; Carson, D., Rasmussen, R., Ensign, P., Huskey, L., Taylor, A., Eds.; Ashgate Publishing: Farnham, UK, 2010 (in press).

37. Holmes, J. Diversity and change in Australia's rangelands: A post-productivist transition with a difference? Trans. Inst. Brit. Geogr. 2002, 27, 362-384.

38. Halseth, G.; Ryser, L.; Sullivan, L. Service provision as part of resource town transition planning: A case from northern British Columbia. In Opportunities and Actions in the New Rural Economy; Bruce, D., Lister, G., Eds.; Rural and Small Town Programme, Mount Allison University: Sackville, NB, Canada, 2003; pp. 29-56.

39. Kellerman, A. Transitions in the Meanings of Frontiers: From Settlement Advance to Regional Development. J. Geogr. 1997, 96, 230-244.

40. Taylor, A.; Carson, D. Indigenous mobility and the Northern Territory Emergency Response. People Place 2009, 17, 29-38.

41. Taylor, A.; Larson, S.; Stoeckl, N.; Carson, D. The haves and have nots in Australia's Tropical North-New perspectives on a persisting problem. Geogr. Res. 2010, (in press).

42. Lockie, S.; Franettovich, M.; Petkova-Timmer, V.; Rolfe, J.; Ivanova, G. Coal mining and the resource community cycle: A longitudinal assessment of the social impacts of the Coppabella coal mine. Environ. Impact Assess. Rev. 2009, 29, 330-339.

43. Newman, P.; Marinova, D.; Armstrong, R.; Raven, M.; Marley, J.; McGrath, N.; Spring, F. Desert Settlement Typology: Preliminary Literature; Deserk Knowledge Cooperative Research Centre: Alice Springs, Australia, 2008.

44. Dollery, B.; Crase, L.; O'Keefe, S. Improving efficiency in Australian local government: Structural reform as a catalyst for effective reform. Geogr. Res. 2009, 47, 269-279. 
45. Northern Australia Land and Water Taskforce. Sustainable Development of Northern Australia: A Report to Government from the Northern Australia Land and Water Taskforce; Department of Infrastructure, Transport, Regional Development and Local Government: Canberra, Australia, 2009.

46. Grey, J. A Military History of Australia; Cambridge University Press: Cambridge, UK, 2008.

47. Garnett, S.T.; Sithole, B.; Whitehead, P.; Burgess, P.; Johnstone, F.; Lea, T. Healthy Country, Healthy People: Policy Implications of Links between Indigenous Human Health and Environmental Condition in Tropical Australia. Aust. J. Public Adm. 2009, 68, 53-66.

48. Gorman, J.; Pearson, D.; Whitehead, P. Assisting Australian Indigenous resource management and sustainable utilization of species through the use of GIS and environmental modelling techniques. J. Environ. Manag. 2008, 86, 104-113.

49. Richards, G. An essay on Canada's population with remarks on Roderic Beaujot's observations. Can. Stud. Popul. 1986, 13, 193-198.

50. Bone, R. The Geography of the Canadian North: Issues and Challenges, 2nd ed.; Oxford University Press: Oxford, UK, 2003.

51. Schmallegger, D.; Carson, D. Is tourism just another staple? A new perspective on tourism in remote regions. Curr. Issue. Tourism 2010, 13, 201-221.

52. Parnell, N.M.; Broughton, T. Flypast: A Record of Aviation in Australia; Australian Government Publishing Service: Canberra, Australia, 1988.

53. Qantas was known as Queensland and Northern Territory Aerial Service (QANTAS) until 1947.

54. Royal Flying Doctor Service Homepage. Avaliable online: http://www.flyingdoctor. org.au/About-Us/Our-History/ (accessed on 28 February 2010).

55. Centre for Asia Pacific Aviation. Review and Assessment of the Effectiveness of Air Services in Western Australia; Western Australia Department for Planning and Infrastructure: Perth, Australia, 2002.

56. Commonwealth of Australia Law, Civil Aviation Regulations 1988 F2009C00991; Available online: http://www.comlaw.gov.au/comlaw/management.nsf/lookupindexpagesbyid/IP200400553? OpenDocument (accessed on 3 March 2010).

57. Commonwealth of Australia Law, Civil Aviation Safety Regulations 1998 F2009C00994; Available online: http://www.comlaw.gov.au/comlaw/management.nsf/lookupindexpagesbyid/ IP200400891? OpenDocument (accessed on 3 March 2010)

58. Baker, D.C.; Freestone, R. Reconciling Public and Private Interests in the Planning of Development of Airports: The Australian Experience 1995-2008. In Proceedings of the 13th International Planning History Society Conference, Chicago, IL, USA, 10-13 July 2008.

59. Aircraft Owners and Pilots Association of Australia. National Aviation Policy Statement Response to Issues Paper; Avaliable online: http://www.myaip.com/pricingproposal/docs/submissions/ aopa.pdf (accessed on 28 February 2010).

60. Regional Telecommunications Independent Review Committee. Framework for the Future; Commonwealth of Australia: Canberra, Australia, 2008. 
61. Cleary, J. Perspectives on Developing New Cooperative Arrangements for Bush-harvested Bush Tomatoes from Desert Australia; Desert Knowledge Cooperative Research Centre: Alice Springs, Australia, 2009.

(C) 2010 by the authors; licensee MDPI, Basel, Switzerland. This article is an open-access article distributed under the terms and conditions of the Creative Commons Attribution license (http://creativecommons.org/licenses/by/3.0/). 